\title{
GAMBARAN WORK CENTRALITY (STUDI PADA KARYAWAN SWASTA DI JAKARTA)
}

\author{
Rizki Dwi Prasetya1, Yenike Margaret Isak ${ }^{2}$, P. Tommy Y. S. Suyasa ${ }^{3}$ \\ ${ }^{1}$ Program Studi Sarjana Psikologi, Universitas Tarumanagara Jakarta \\ Email: rizki.705170112@stu.untar.ac.id \\ ${ }^{2}$ Program Studi Magister Psikologi, Universitas Tarumanagara Jakarta \\ Email: yenike.717182019@stu.untar.ac.id \\ ${ }^{3}$ Fakultas Psikologi, Universitas Tarumanagara Jakarta \\ Email:tommys@fpsi.untar.ac.id
}

Masuk: 05-05-2021, revisi: 05-08-2021, diterima untuk diterbitkan: 06-08-2021

\begin{abstract}
Work centrality is defined as the extent to which individuals believe that their work plays an important role in their life. This study aims to describe the work centrality of the private employment in Jakarta. Descriptive quantitative was used in this study. The data collection techniques in this study were using snowball sampling and convenience sampling. The participants were 107 private employees in Jakarta. Work centrality was measured using Work Involvement Questionnaire. The results showed that work centrality of the private employees in Jakarta were low. Based on demographic factors, it also shows that the mean value of male gender is lower, but based on other factors, there is a significant relationship to work centrality and the level of education.
\end{abstract}

Keywords: Work centrality, private employee, job, Jakarta

\begin{abstract}
ABSTRAK
Work centrality diartikan sebagai sejauh mana individu percaya bahwa pekerjaan mereka memainkan peran penting dalam kehidupan. Penelitian ini bertujuan untuk mengetahui gambaran work centrality pada karyawan swasta di Jakarta. Jenis penelitian ini adalah deskriptif kuantitatif. Teknik pengambilan data dalam penelitian ini adalah menggunakan snowball sampling dan convenience sampling. Subjek pada penelitian ini melibatkan 107 karyawan swasta di Jakarta. Alat ukur yang digunakan dalam penelitian ini adalah kuesioner work centrality yang telah diadaptasi dari Work Involvement Questionnaire. Hasil penelitian ini menunjukkan bahwa gambaran work centrality secara umum pada karyawan swasta di Jakarta cenderung rendah. Berdasarkan faktor demografis juga menunjukkan bahwa nilai rerata pada jenis kelamin laki-laki lebih rendah, namun berdasarkan faktor lainnya terdapat hubungan yang signifikan terhadap work centrality dengan tingkat pendidikan.
\end{abstract}

Kata Kunci: Work centrality, karyawan swasta, pekerjaan, Jakarta

\section{PENDAHULUAN}

\section{Latar Belakang}

Bekerja merupakan upaya dalam melakukan atau melaksanakan tugas yang membutuhkan waktu maupun tenaga untuk memperoleh imbalan. Secara sederhana bekerja dapat diartikan sebagai usaha yang dilakukan manusia untuk mendapatkan penghasilan demi memenuhi tujuan tertentu (Jaenudin, 2018). Dengan bekerja seseorang bisa memenuhi kebutuhan hidupnya dengan baik. Secara umum tujuan bekerja adalah untuk mencari nafkah atau mata pencaharian dalam memenuhi kebutuhannya untuk bertahan atau melangsungkan kehidupannya (Kurniawan, 2019). Menurut Abadini dan Wuryaningsih (2019) sebagian besar pekerja di Jakarta adalah pekerja kantoran. Mereka menghabiskan waktu lebih dari 8 jam di kantor dan 2 hingga 4 jam di perjalanan, baik menuju kantor ataupun pulang ke rumah. Sebagian besar waktu dalam hidup kita habiskan untuk bekerja.

Karyawan yang mengabdikan sebagian besar waktunya untuk bekerja secara konsisten dan berupaya dalam melakukan setiap pekerjaan yang berkualitas memiliki dedikasi terhadap perusahaan atau organisasinya. Pekerjaan merupakan bagian dari hidup. Dilansir dari Kumparan 
(April, 2018) kehidupan manusia sehari-hari tidak akan lepas dengan yang namanya kebutuhan dan sebagai cara untuk memenuhi kebutuhan tersebut adalah dengan bekerja. Namun sebagian besar individu bekerja dilatar belakangi oleh keluarga. Bekerja merupakan salah satu upaya anggota keluarga dalam meningkatkan kesejahteraan keluarga. Keluarga merupakan sistem pendukung pertama dan utama bagi individu. Dalam hal ini peneliti menggunakan partisipan pada karyawan swasta di Jakarta. Karyawan swasta, yaitu karyawan yang bekerja pada perusahaan swasta atau perusahaan di luar instansi pemerintah dan digaji oleh perusahaan swasta tersebut (Ulty, Maret 2020).

Keyakinan individu tentang pentingnya pekerjaan dalam kehidupan seseorang disebut dengan istilah work centrality (Kostek, 2012). Work centrality mengacu pada sejauh mana individu memandang pekerjaan sebagai bagian yang utama dalam hidupnya. Karyawan yang memiliki work centrality juga dapat menghabiskan waktu demi suatu pekerjaan serta secara emosional terikat dengan organisasi mereka. Dengan pilihan untuk terus bekerja maka berdampak juga terhadap jam kerja. Mereka yang menganggap pekerjaan sebagai bagian penting dari kehidupan cenderung bekerja dalam waktu lama. Hal ini berdampak pada karyawan untuk memilih pekerjaan tambahan atau bekerja lembur (Snir \& Harpaz, 2002).

Work centrality adalah keyakinan normatif tentang nilai dan pentingnya pekerjaan dalam kehidupan seseorang, dan itu merupakan fungsi dari keadaan masa lalu, budaya seseorang atau sosialisasi (Kanungo, 1982). Hal ini dapat diartikan bahwa individu yang bekerja atau memiliki pekerjaan akan selalu mengedepankan nilai-nilai dari pekerjaan tersebut dan menganggap bahwa pekerjaan adalah hal yang paling utama atau penting dalam hidupnya. Individu yang memiliki work centrality akan mempersepsikan bahwa pekerjaan sangat berpengaruh terhadap kehidupannya.

Terdapat tiga faktor yang mempengaruhi work centrality (Kostek, 2012), diantaranya ada jenis kelamin, dalam hal ini laki-laki cenderung menginvestasikan lebih banyak sumber daya dalam mengembangkan karir mereka dan memiliki kesan identitas mereka sebagai pekerja menjadi lebih umum sementara perempuan cenderung mengalokasikan sumber daya mereka untuk pembangunan keluarga, dan memandang peran mereka di tempat kerja sebagai bagian yang kurang penting dari diri mereka sendiri. Dalam penelitian yang dilakukan oleh Schmidt dan Lee (2008) menemukan bahwa laki-laki memiliki work centrality yang lebih tinggi dibandingkan perempuan. Selanjutnya terdapat faktor usia, pada saat memasuki usia pertengahan di masa pekerjaan, individu memiliki lebih banyak tanggung jawab untuk memenuhi kebutuhan finansial sehingga mereka memberikan kontribusi yang signifikan terhadap pekerjaannya (Kostek, 2012). Penelitian lain telah menunjukkan hubungan positif antara usia dan work centrality, yang memungkinkan pekerjaan menjadi bagian lebih kuat dari identitas mereka (Arvey et al., 2004). Namun menurut Hadju dan Sik (2018) work centrality pada karyawan yang berusia 43 hingga 47 tahun mengalami peningkatan, akan tetapi pada periode selanjutnya cenderung menurun. Hal ini dapat dikatakan bahwa semakin tua usia maka semakin rendah work centrality pada karyawan.

Berdasarkan faktor pendidikan, dalam tingkat pendidikan, pengetahuan dan keterampilan memiliki peran yang cukup penting terkait pekerjaan seseorang. Banyak orang menginvestasikan waktunya untuk mempersiapkan pekerjaan dengan mengikuti program pelatihan atau mencari pendidikan tinggi (Kostek, 2012). Semakin tinggi tingkat pendidikannya, semakin besar tuntutan kognitif yang dibebankan kepada pekerja dalam peran kerjanya. Hal ini mempengaruhi cara individu mengevaluasi pengalaman kerjanya. Tingkat pendidikan juga dapat memengaruhi 
karyawan memiliki work centrality, hal tersebut dapat dilihat dari bagaimana upaya karyawan dalam memajukan suatu organisasi serta memiliki loyalitas yang besar pada organisasinya.

Work centrality digambarkan sebagai suatu konstruksi yang terdiri dari komitmen umum dalam bekerja (Paullay et al., 1994). Seseorang yang menghargai pekerjaan sebagai bagian penting dari kehidupan seharusnya lebih menghargai organisasi, karena organisasi sebagai wadah atau tempat untuk mengekspresikan minat dalam bekerja. Mereka yang sangat menghargai pekerjaan cenderung menumbuhkan hubungan afektif terhadap organisasinya, dengan demikian hal tersebut dapat mengembangkan rasa komitmen dan secara tidak langsung mereka terlibat dalam pekerjaan. Menurut Morelli dan Cunningham (2012) menunjukkan bahwa kepribadian memiliki pengaruh atas pentingnya sumber daya yang berkaitan dengan nilai-nilai terhadap pekerjaannya.

Dalam lintas budaya beberapa negara seperti Brazil, Jerman, Hongaria, Kazakhstan, Korea Selatan, dan Amerika Serikat memiliki tingkat asertif yang tinggi terhadap pekerjaan. Individu dengan work centrality tinggi dapat mengidentifikasi peran pekerjaan mereka dan melihat pekerjaan sebagai aspek penting dalam hidup mereka (Diefendorff et al., 2002). Individu dengan work centrality yang tinggi juga mampu menemukan makna serta berkompeten dalam peran kerja mereka (Ugwu \& Igbende, 2017). Karyawan cenderung menghargai persaingan dan menempatkan nilai tinggi pada pentingnya tugas yang dilakukan selama bekerja. Dengan demikian bagi karyawan, peran kerja lebih penting dalam hidup mereka daripada individu dengan work centrality yang rendah (Bal \& Kooij, 2011). Individu dengan work centrality yang tinggi percaya bahwa pekerjaan adalah bagian terpenting dalam hidup dan merupakan sesuatu yang harus dilakukan demi kepentingannya sendiri (Hu et al., 2018). Individu seperti itu kemungkinan besar akan lebih mudah memahami dan terlibat dalam peranan pekerjaan mereka. Menurut Ugwu dan Igbende (2017) orang dengan work centrality yang tinggi menemukan makna dan mengidentifikasi dengan sangat kuat peran kerjanya.

\section{Rumusan Masalah}

Berdasarkan latar belakang yang telah diuraikan di atas, maka rumusan masalah penelitian ini adalah: (a) bagaimana gambaran work centrality pada karyawan swasta di Jakarta?; (b) komponen indikator work centrality manakah yang memiliki nilai tertinggi?; (c) komponen indikator work centrality manakah yang memiliki nilai terendah?

\section{METODE PENELITIAN}

Penelitian ini merupakan penelitian deskriptif kuantitatif yang melibatkan 107 orang karyawan swasta di Jakarta sebagai partisipan. Teknik pengambilan sampel yang digunakan adalah nonprobability sampling, secara spesifik yaitu snowball sampling dan convenience sampling.

Gambaran partisipan dalam penelitian ini dibagi menjadi tiga bagian, yaitu (a) jenis kelamin; (b) usia; dan (c) tingkat pendidikan. Partisipan berjenis kelamin laki-laki sebanyak 50 partisipan (47\%) dan berjenis kelamin perempuan sebanyak 57 partisipan (53\%). Dari segi usia, dalam penelitian ini partisipan memiliki rentang usia antara 20 tahun sampai 53 tahun. Tingkat pendidikan partisipan cukup beragam dimulai dari tingkat SMA/SMK hingga Strata 2 (S2).

Pengambilan data ini dilakukan secara daring melalui tautan Google Form dengan cara menyebarkan link kuesioner yang dibagikan langsung kepada partisipan maupun teman peneliti yang mempunyai kenalan dengan karyawan swasta. Penulis menggunakan kuesioner Work Centrality yang telah diadaptasi dari Work Involvement Questionnaire yang disusun oleh Kanungo (1982). Alat ukur ini merupakan alat ukur yang tidak memiliki dimensi atau unidimensional. 
Alat ukur ini terdiri dari enam butir pernyataan dan disusun menggunakan Skala Likert dengan rentang jawaban satu sampai lima. Kuesioner ini telah dimodifikasi dengan dosen pembimbing selaku expert judgment alat ukur. Partisipan diminta untuk memilih jawaban antara pekerjaan dan keluarga. Pekerjaan dan keluarga adalah dua domain penting dalam kehidupan seseorang, dan masing-masing mendapat perhatian yang cukup besar (Carr, 2007). Butir-butir tersebut diantaranya: "Hal terpenting bagi saya dalam hidup ini adalah..." Skor yang menunjukkan tingkat seberapa penting individu menganggap pekerjaan sebagai hal terpenting dari hidup dan "Kebanyakan waktu saya dihabiskan untuk..." semakin tinggi skor work centrality, maka semakin banyak individu menghabiskan waktunya untuk pekerjaan.

Untuk menghitung reliabilitas alat ukur Work Centrality digunakan teknik perhitungan Alpha Cronbach's dengan nilai koefisien sebesar $0.82(\alpha=0.82)$. Hasil analisa menunjukan bahwa dari enam butir pernyataan yang ada, tidak ada butir yang memiliki nilai corrected item-total correlation lebih kecil dari 0.3 sehingga tidak ada butir pernyataan yang dibuang.

\section{HASIL DAN PEMBAHASAN}

Penulis melakukan uji normalitas dengan menggunakan One-Sample Kolmogorov-Smirnov Test. Hal ini bertujuan untuk mengetahui apakah data terdistribusi normal atau tidak. Uji normalitas dilakukan dalam menentukan teknik yang akan digunakan untuk pengujian data selanjutnya. Berdasarkan hasil uji normalitas, diketahui data terdistribusi tidak normal, karena $\mathrm{p}=0.001<0.05$. Data yang terdistribusi tidak normal akan diolah dan dianalisis dengan menggunakan teknik nonparametric measurement. Berdasarkan hasil pengolahan data menggunakan analisis Descriptive Statistic telah diperoleh hasil gambaran secara umum Work Centrality pada karyawan swasta di Jakarta. Nilai median serta modus Work Centrality yang diperoleh dari karyawan swasta di Jakarta adalah Median $=2.66$ dan Modus $=3.00$. Nilai rerata Work Centrality yang diperoleh dari karyawan swasta di Jakarta adalah $\mathrm{M}=2,50$ dan $\mathrm{SD}=0,75$. Rentang kontinum pada Work Centrality minimal adalah satu dan maksimal adalah lima. Sehingga berdasarkan nilai median Work Centrality dari para karyawan swasta yang berada di Jakarta cenderung rendah dari pada titik tengah alat ukur, yaitu tiga.

Terdapat enam indikator dalam pengukuran tinggi atau rendahnya tingkat Work Centrality pada karyawan swasta di Jakarta dan dari ke enam indikator tersebut telah dilakukan uji reliabilitas. Pada uji reliabilitas tidak terdapat butir yang tidak layak untuk digunakan, sehingga tidak ada butir yang harus di gugurkan serta seluruh nilai r diatas 0,2 .

\section{Tabel 1}

Gambaran Work Centrality Ditinjau Berdasarkan Kategori Usia

\begin{tabular}{|c|c|c|c|c|c|c|c|c|c|c|c|c|c|}
\hline \multirow[t]{2}{*}{ VARIABEL } & \multicolumn{2}{|c|}{$20-24$} & \multicolumn{2}{|c|}{$25-29$} & $30-34$ & \multicolumn{2}{|c|}{$35-39$} & \multicolumn{2}{|c|}{$40-44$} & \multicolumn{2}{|c|}{$45-49$} & \multicolumn{2}{|c|}{$50-53$} \\
\hline & $M$ & $S D$ & $M$ & $S D$ & $M S D$ & $\bar{M}$ & $S D$ & $M$ & $S D$ & $M$ & $S D$ & $M$ & $S D$ \\
\hline $\begin{array}{l}\text { Total Work } \\
\text { Centrality }\end{array}$ & 2,69 & 0,74 & 2,45 & 0,75 & $* \mathbf{2 , 8 3} * 0,88$ & 2,20 & 0,83 & 2.52 & 0,45 & 2,15 & 0,82 & 2,19 & 0,54 \\
\hline $\begin{array}{c}\text { Total } \\
\text { Responden }\end{array}$ & & 47 & & 20 & 4 & & 4 & & 8 & & 18 & & 6 \\
\hline Total & & & & & & 10 & & & & & & & \\
\hline
\end{tabular}

Telah ditemukan nilai rerata Work Centrality yang paling tinggi dialami terdapat pada partisipan yang berusia rentang $30-34$ tahun $(M=2.83 ; S D=0.88)$. 


\section{Tabel 2}

Gambaran Work Centrality Ditinjau Berdasarkan Jenis Kelamin

\begin{tabular}{ccccc}
\hline Jenis Kelamin & $\begin{array}{c}\text { Total } \\
\text { Partisipan }\end{array}$ & Mean Rank & SD & $\boldsymbol{p}$ \\
\hline Laki-laki & 50 & 2.44 & 0.83 & 0.404 \\
Perempuan & 57 & 2.55 & 0,68 & \\
\hline Total & 107 & & & \\
\hline
\end{tabular}

Telah diketahui bahwa rerata dari Work Centrality yang mendapat nilai tertinggi dialami pada partisipan dengan jenis kelamin wanita, di mana nilai rerata pada Work Centrality $(M=2.55 ; S D$ $=0.68$ ). Sedangkan pada partisipan dengan jenis kelamin laki-laki, di mana nilai rerata pada Work Centrality $(M=2.44 ; S D=0.83)$.

Tabel 3. Gambaran Work Centrality Ditinjau Berdasarkan Pendidikan

\begin{tabular}{ccccc}
\hline Pendidikan & Mean Rank & SD & Total Partisipan & $\boldsymbol{p}$ \\
\hline SMA/SMK & 2.38 & 0.77 & 37 & 0.234 \\
Diploma & 1.83 & - & 1 & \\
Sarjana (S1) & 2.51 & 0.77 & 59 & \\
Magister (S2) & 2.93 & 0.43 & 10 & \\
\hline Total & & & & \\
\end{tabular}

Berdasarkan tingkat pendidikan, pengetahuan dan keterampilan memiliki peran yang cukup penting terkait pekerjaan seseorang. Banyak orang menginvestasikan waktunya untuk mempersiapkan pekerjaan dengan mengikuti program pelatihan atau mencari pendidikan tinggi (Kostek, 2012). Dari hasil analisis berdasarkan tingkat pendidikan diketahui bahwa rerata dari Work Centrality yang mendapat nilai tertinggi yaitu pada tingkat Magister (S2) $(\mathrm{M}=2.93 ; \mathrm{SD}=$ $0.43)$.

\section{KESIMPULAN DAN SARAN}

Berdasarkan hasil analisis data yang telah dilakukan sebelumnya, maka peneliti dapat menyimpulkan gambaran work centrality secara umum pada karyawan swasta di Jakarta dinilai cenderung rendah. Peneliti menemukan gambaran work centrality terhadap karyawan swasta di Jakarta per indikator secara detail dan menemukan nilai tertinggi dari indikator yaitu "Waktu partisipan dihabiskan untuk bekerja" dan peneliti telah menemukan gambaran work centrality terhadap karyawan swasta di Jakarta per indikator secara detail dan menemukan nilai terendah dari indikator "hal terpenting bagi partisipan dalam hidup ini adalah keluarga."

Berdasarkan analisis tambahan mengenai usia, hasilnya menunjukkan bahwa nilai rerata work centrality yang paling tinggi dialami partisipan yang berusia rentang $30-34$ tahun $(\mathrm{M}=2.83$; SD $=0.88$ ). Hal ini sejalan dengan Kostek (2012) yang menyatakan pada saat memasuki usia pertengahan di masa pekerjaan, individu memiliki lebih banyak tanggung jawab untuk memenuhi kebutuhan finansial sehingga mereka memberikan kontribusi yang signifikan terhadap pekerjaannya. 
Peneliti melanjutkan hasil analisis data tambahan berdasarkan jenis kelamin, hasilnya menunjukkan bahwa nilai rerata jenis kelamin wanita lebih tinggi $(\mathrm{M}=2.55 ; \mathrm{SD}=0.68)$ dibandingkan pria $(\mathrm{M}=2.44 ; \mathrm{SD}=0.83)$. Hal ini tidak sejalan dengan penelitian sebelumnya yang menyatakan bahwa laki-laki cenderung menginvestasikan lebih banyak sumber daya dalam mengembangkan karir mereka dan memiliki kesan identitas mereka sebagai pekerja menjadi lebih umum sementara perempuan cenderung mengalokasikan sumber daya mereka untuk pembangunan keluarga, dan memandang peran mereka di tempat kerja sebagai bagian yang kurang penting dari diri mereka sendiri (Kostek, 2012).

Berdasarkan analisis tambahan berdasarkan tingkat pendidikan, hasilnya menunjukkan bahwa rerata dari work centrality yang mendapat nilai tertinggi yaitu pada tingkat Magister (S2) (M = 2.93; SD = 0.43). Hal ini sejalan dengan penelitian sebelumnya yang menyatakan tingkat pendidikan dapat memengaruhi karyawan memiliki work centrality dan dapat dilihat dari bagaimana upaya karyawan dalam memajukan suatu organisasi serta memiliki loyalitas yang besar pada organisasinya (Kostek, 2012).

Terkait dengan hasil penelitian di atas, penulis berharap penelitian ini dapat memberikan sumbangan ilmu dan manfaat bagi perkembangan ilmu Psikologi terutama dalam bidang Psikologi Industri dan Organisasi. Saran yang dapat penulis berikan terhadap bidang Psikologi Industri dan Organisasi adalah bahwa work centrality merupakan variabel yang sangat penting untuk dibahas dan berdampak terhadap perilaku kerja karyawan.

Saran penulis terhadap penelitian selanjutnya adalah untuk lebih menguji faktor-faktor demografis dan memperbanyak pendalaman terkait teori dari work centrality dengan variabel psikologi lainnya agar mendapatkan data yang lebih beragam. Saran yang dapat penulis berikan kepada praktisi yang bergerak di bidang Industri dan Organisasi adalah work centrality dapat menjadi faktor yang menghantarkan organisasi untuk mewujudkan komitmen dalam bekerja, sehingga praktisi di bidang Industri dan Organisasi perlu menciptakan lingkungan organisasi yang aman dan nyaman bagi kesejahteraan karyawan dalam bekerja.

\section{Ucapan Terima Kasih (Acknowledgement)}

Terima kasih kepada pihak-pihak yang telah berkontribusi dan mendukung penelitian ini, khususnya kepada 107 karyawan swasta di Jakarta yang menjadi partisipan penelitian.

\section{REFERENSI}

Abadini, D., \& Wuryaningsih, C. E. (2019). Determinan aktivitas fisik orang dewasa pekerja kantoran di Jakarta tahun 2018. Jurnal Promosi Kesehatan Indonesia, 14(1), 15-28.

Arvey, R. D., Harpaz, I., \& Liao, H. (2004). Work centrality and post-award work behavior of lottery winners. The Journal of Psychology, 138, 404-420. https://doi.org/10.3200/JRLP. 138.5.404-420.

Bal, P. M., \& Kooij, D. (2011). The relations between work centrality, psychological contracts, and job attitudes: The influence of age. European Journal of Work and Organizational Psychology, 20(4), 497-523.

Diefendorff, J. M., Brown, D. J., Kamin, A. M., \& Lord, R. G. (2002). Examining the roles of job involvement and work centrality in predicting organizational citizenship behaviors and job performance. Journal of Organizational Behavior, 23, 93 - 108. 
Hu, S., Jiang, L., Probst, T. M., \& Liu, M. (2018). The relationship between qualitative job insecurity and subjective well-being in Chinese employees: The role of work-family conflict and work centrality. Economic and Industrial Democracy. https://journals. sagepub.com/doi/full/10.1177/0143831X18759793

Kanungo, R. N. (1982). Measurement of job and work involvement. Journal of Applied Psychology, 67, 341-349. https://doi.org/10.1037/0021-9010.67.3.341

Kostek, J. A. (2012). Work centrality: A meta-analysis of the nomological network (Master's thesis). Bowling Green State University, $\mathrm{OH}$.

Kumparan. (2018, 10 April). Alasan mengapa anda harus bekerja keras. https://kumparan.com/tog-indonesia/mengapa-anda-harus-bekerja-keras

Morelli, N. A., \& Cunningham, C. J. (2012). Not all resources are created equal: COR theory, values, and stress. The Journal of Psychology, 146(4), 393-415.

Paullay, I. M., Alliger, G. M., \& Stone-Romero, E. F. (1994). Construct validation of two instruments designed to measure job involvement and work centrality. Journal of Applied Psychology, 79(2), 224

Schmidt, J. A., \& Lee, K. (2008). Voluntary retirement and organizational turnover intentions: The differential associations with work and non-work commitment constructs. Journal of Business and Psychology, 22(4), 297-309.

Snir, R., \& Harpaz, I. (2002). Work-leisure relations: Leisure orientation and the meaning of work. Journal of Leisure Research, 34(2), 178-203.

Ugwu, F. O., \& Igbende, D. A. (2017). Going beyond borders: Work centrality, emotional intelligence and employee optimism as predictors of organizational citizenship behavior. Cogent Psychology, 4(1). https://www.cogentoa.com/article/10.1080/23311908. 2017.1362805

Ulty. (2020, Maret 25). Lancang kuning.com media masa kini: Macam-macam personil administrasi. Diakses pada 4 Januari 2021, https://lancangkuning.com/post/17343/macam-macam-personiladministrasi 